\title{
Implikasi Putusan Mahkamah Konstitusi Nomor 95/PUU-XII/2014 Terhadap Tindak Pidana Kehutanan
}

\author{
Imran Siswadi \\ Prodi Ilmu Hukum, Institut Ilmu Sosial dan Ilmu Budaya Samawa Rea \\ EmailKorespondensi imransiswadi24@gmail.com
}

Abstrak. Kehadiran Undang-Undang Nomor 18 Tahun 2013 tentang Pemberantasan dan Pencegahan Perusakan Hutan (UUPPPH) dan Undang-Undang 41 Tahun 1999 tentang Kehutanan (UU Kehutanan) dimaksudkan dalam rangkan menjaga kelestarian, kedayagunaa dan kemanfaatannya untuk menopang kehidupan dan menjadi sumber kemakmuran rakyat. Tindak pidana kehutanan dalam UU ini telah menimbulkan masalah multidimensi yang berhubungan dengan aspek ekonomi, sosial, budaya, dan lingkungan. Hal tersebut merupakan konsekuensi logis dari fungsi hutan yaitu: fungsi produksi (ekonomi), fungsi lingkungan (ekologi) dan fungsi sosial.Persoalan klaim kawasan hutan yang dilakukan oleh Pemerintah dengan menerbitkan izinizin usaha diatas tanah yang baru ditunjuk sebagai kawasan hutan, tetapi belum dikukuhkan atau ditetapkan keberadaannya sebagai hutan tetap. Mengingat putusan MK sebelumnya No. 45/ PUUIX/2011 menafsirakan Pasal 1 angka (3) UU Kehutanan bahwa penunjukan merupakan tahapan awal dalam pengukuhan kawasan hutan. Tindak pidana kehutanan yang diperuntukan agar pengelolaan serta pemanfaatan sumber daya hutan harus tetap menjaga kelestarian dan dilakukan secara arif dan bijaksana, agar tidak terjadi kerusakan.

Kata Kunci: Implikasi, Tindak Pidana, Kehutanan

\section{PENDAHULUAN}

\section{Latar Belakang}

Potensi sumber daya alam Indonesia sangat besar dan beraneka ragam jenisnya. Hutan, merupakan salah satu kekayaan alam bangsa Indonesia yang sangat berharga dan memberi manfaat bagi umat manusia. Hutan sebagai karunia Tuhan Yang Maha Esa wajib disyukuri, diurus dan dimanfaatkan secara optimal untuk sebesar-besarnya kemakmuran rakyat. Indonesia dengan potensi sumber daya hutan yang sangat besar tersebut mampu mendorong pertumbuhan ekonomi nasional. Tetapi bertepatan dengan itu konsekuensinya terdapat dampak negatif atas pengelolaan hutan. Pengelolaan hutan yang dilakukan saat ini telah menimbulkan dampak buruk bagi lingkungan hidup baik dari segi ekonomi, kesehatan dan sosial budaya seperti kerusakan hutan yang

Jurnal Ilmu Sosial dan Pendidikan disebabkan oleh aktivitas perusahaanperusahaan besar di dalam wilayah hutan.

Total luas hutan di Indonesia mencapai 180 juta hektar, sebanyak 21 persen atau setara dengan 26 juta hektar telah di jarah total sehingga tidak memiliki tegakan pohon lagi. Artinya, 26 juta hektar hutan di Indonesia telah musnah. Selain itu, 25 persen lainnya atau setara dengan 48 juta hektar juga

mengalamideforentasi dan dalam kondisi rusak. 180 juta hektar total luas hutan di Indonesia hanya sekitar 23 persen atau setara dengan 43 juta hektar yang masih terbebas dari deforentasi (kerusakan hutan). Perlakuan atas hutan tersebut terjadi demi kepentingan bisnis dan investasi di sektor perkebunan, industri kehutanan, maupun pertambangan (Aminuddin dkk, 2019, hlm 234)

Bagi masyarakat adat dan masyarakat yang tinggal disekitar dan dalam kawasan 


\section{Terakreditasi Peringkat 5 (No. SK: 85/M/KPT/2020)}

hutan, hutan merupakan bagian dari wilayah hidup, sebagai sumber gantungan kehidupan dan faktor penentu eksistensi mereka. Dari hutan masyarakat adat mendapatkan sumber-sumber obat tradisional mereka. Hilang dan rusaknya hutan menjadikan hilang dan rusaknya kehidupan masyarakat adat dan masyarakat sekitar kawasan hutan. Ketergantungan terhadap sumber daya hutan ini bisa dilihat dari 31.957 desa yang berada disekitar dan didalam kawasan hutan di Indonesia, 71,06 \% tergantung pada kawasan hutan.(Komnas HAM 2016) Banyak sekali wilayah adat termasuk hutan adat yang diklaim oleh Pemerintah secara sepihak sebagai kawasan hutan dan kemudian memunculkan tumpang-tindih klaim yang berdampak pada konflik-konflik antara masyarakat adat, Pemerintah dan perusahaan.

Kehadiran Undang-Undang Nomor 18 Tahun 2013 tentang Pemberantasan dan Pencegahan Perusakan Hutan (UUPPPH) dan Undang-Undang 41 Tahun 1999 tentang Kehutanan (UU Kehutanan) dimaksudkan dalam rangkan menjaga kelestarian, kedayagunaa dan kemanfaatannya untuk menopang kehidupan dan menjadi sumber kemakmuran rakyat. Tindak pidana kehutanan dalam UU ini telah menimbulkan masalah multidimensi yang berhubungan dengan aspek ekonomi, sosial, budaya, dan lingkungan. Hal tersebut merupakan konsekuensi logis dari fungsi hutan yaitu: fungsi produksi (ekonomi), fungsi lingkungan (ekologi) dan fungsi sosial.

Persoalan klaim kawasan hutan yang dilakukan oleh Pemerintah dengan menerbitkan izin-izin usaha diatas tanah yang baru ditunjuk sebagai kawasan hutan, tetapi belum dikukuhkan atau ditetapkan keberadaannya sebagai hutan tetap. Mengingat putusan MK sebelumnya No. 45/ PUUIX/2011 menafsirakan Pasal 1 angka (3) UU Kehutanan bahwa penunjukan merupakan tahapan awal dalam pengukuhan kawasan hutan. Tindak pidana kehutanan yang diperuntukan agar pengelolaan serta pemanfaatan sumber daya hutan harus tetap menjaga kelestarian dan dilakukan secara arif dan bijaksana, agar tidak terjadi kerusakan.

Namun tidak sedikit hutan adat dikuasai oleh Negara dengan sistem penunjukan yang membuat Negara dengan mudah mengklaim setiap kawasan sebagai hutan Negara. Permasalahan ini terus menuai protes oleh masyarakat yang merasa dikriminalisasi oleh Negara lewat ketentuan di dalam undang-undang kehutanan.

Akibat dari klaim Negara tersebut membuat aktifitas masyarakat adat di dalam hutan adat seperti menebang pohon di hutan adat, memungut hasil hutan, melakukan ritual adat atau mengembalakan ternak tanpa izin dianggap sebagai sebuah tindak pidana berdasarkan UUPPPH dan UU Kehutanan, serta adanya berbagai kasus dimana masyarakat yang hidup secara turun temurun di sekitar dan dalam kawasan hutan karena sekedar memenuhi kebutuhan ekonomi menebang, mengambil atau membawa dan memanfaatkan sebatang kayu dari hutan tanpa izin pejabat yang berwenang dikenakan tindak pidana illegal logging.

UUPPPH dan UU Kehutanan seakanakan menjadi senjata ampuh untuk memenjarakan warga masyarakat sipil yang mencoba mempertahankan wilayahnya, sehingga tercatat lebih dari 50 perkara pidana telah digelar dan/atau diputuskan. Berlakunya sejumlah ketentuan dalam UUPPPH dan UU Kehutanan telah berdampak kepada kriminalisasi terhadap masyarakat yang berada di dalam dan sekitar kawasan hutan, serta ketidakpastian hukum mengenai status kawasan hutan yang menimbulkan konflik tenurial kehutanan, dan kondisi hutan yang semakin memburuk. (Yance dkk, 1, 2015) 
Tumpang tindih penafsiran regulasi dibidang kehutanan ini membawa 10 pihak yang terdiri dari Masyarakat Hukum Adat Nagari Guguk Malalo, Sumatra Barat, bersama dengan tiga orang Individu: Edi Kuswanto bin Kamarullah dari Sumbawa (Nusa Tenggara Barat), Rosidi bin Parmo dari Kendal (Jawa Tengah) dan Mursid bin Sarkaya dari Lebak (Banten), beserta dengan enam badan hukum antara lain Yayasan Wahana Lingkungan Hidup (Walhi), Aliansi Masyarakat Adat Nusantara (AMAN), Konsorsium Pembaruan Agraria (KPA), Perkumpulan Sawit Watch, Indonesia Corruption Watch (ICW), dan Yayasan Silvagama, mengajukan permohonan uji materiil terhadap 19 (sembilan belas) ketentuan dalam UUPPPH dan 4 (empat) ketentuan dalam UU Kehutanan ke Mahkamah Konstitusi (MK) dengan registrasi perkara konstitusi nomor 95/PUU$\mathrm{XII} / 2014$.

Amar putusan MK Nomor 95/PUUXII/2014 menyatakan bahwa mengabulkan sebagian permohonan yang diajukan oleh Pemohon, sebagian permohonan dinyatakan tidak dapat diterima, dan sebagian lagi dinyatakan ditolak. Ketentuan yang dikabulkan permohonan pengujiannya adalah Pasal 50 ayat 3 huruf (e) dan (i) UU Kehutanan.

Sebelum putusan MK, ketentuan Pasal 50 ayat 3 huruf (e) dan (i) UU Kehutanan mengatur larangan bagi setiap orang yang: “(e) menebang pohon atau memanen atau memungut hasil hutan di dalam hutan tanpa memiliki hak atau izin dari pejabat yang berwenang. (i) menggembalakan ternak di dalam kawasan hutan yang tidak ditunjuk secara khusus untuk maksud tersebut oleh pejabat yang berwenang". Setelah putusan MK maka ketentuan Pasal 50 ayat 3 huruf (e) dan (i) berbunyi: “(e) menebang pohon atau memanen atau memungut hasil hutan di dalam hutan tanpa memiliki hak atau izin dari pejabat yang berwenang kecuali masyarakat yang hidup secara turun temurun di dalam hutan dan tidak ditujukan untuk kepentingan komersial. (i) menggembalakan ternak di dalam kawasan hutan yang tidak ditunjuk secara khusus untuk maksud tersebut oleh pejabat yang berwenang kecuali masyarakat yang hidup secara turun temurun di dalam hutan dan tidak ditujukan untuk kepentingan komersial". Putusan MK ini memberikan fondasi penting yang perlu diperhatikan oleh pembentuk dan pelaksana undang-undang untuk menerapkan ketentuan pidana di bidang kehutanan.

\section{Rumusan Masalah}

1) Bagaimana implikasi hukum tindak pidana kehutanan pasca putusan MK Nomor 95/PUU-XII/2014?

2) Bagaimana kebijakan hukum pidana dalam tindak pidana kehutanan pasca putusan MK Nomor 95/PUU-XII/2014?

\section{KAJIAN TEORI}

\section{Teori Tindak Pidana}

Tindak pidana (Strafbaar Feit) adalah suatu perbuatan yang pelakunya dapat dikenakan hukuman pidana. Pelaku dapat dikatakan merupakan "subjek" tindak pidana. (Wirjono, 2003, 59) Tindak pidana atau perbuatan pidana juga disebut delik (delict) yang berasal dari bahasa Latin delictum. Tindak pidana adalah suatu perbuatan yang dilarang oleh suatu aturan hukum, di mana larangan tersebut disertai dengan ancaman (sanksi) yang berupa pidana tertentu sebagai pertanggungjawabkannya. (Andi Hamzah, 2001, 15). Menurut Barda Nawawi Arief, tindak pidana adalah perbuatan melakukan atau tidak melakukan sesuatu yang oleh peraturan perundang-undangan dinyatakan sebagai perbuatan yang dilarang dan diancam dengan pidana. (Barda Nawari, 2002, 37) 
Unsur-unsur tindak pidana dapat dibedakan dari dua sudut pandang yaitu secara teoritis dan dari sudut UndangUndang. Maksud teoritis ialah berdasarkan pendapat para ahli hukum, yang tercermin pada bunyi rumusannya, sedangkan dari sudut Undang-Undang adalah bagaimana kenyataan tindak pidana itu dirumuskan menjadi tindak pidana tertentu dalam pasalpasal peraturan perundang-undangan yang ada.

Unsur tindak pidana menurut beberapa ahli (Adami, 2000, 79)

1) Menurut Moeljatno, unsur tindak pidana adalah: a) Perbuatan; b) Yang dilarang (oleh aturan hokum); c) Ancaman pidana (bagi yang melanggar larangan).

2) Menurut R.Tresna, tindak pidana terdiri dari unsur-unsur, yakni: a) Perbuatan/rangkaian perbuatan (manusia); b) Yang bertentangan dengan peraturan perundang-undangan; c) Diadakan tindakan penghukuman.

Unsur rumusan tindak pidana tertentu dalam KUHP dapat diketahui ada 8 unsur tindak pidana, yaitu: a) Unsur tingkah laku; b) Unsur melawan hokum; c) Unsur kesalahan; d) Unsur akibat konstitutif; e) Unsur keadaan yang menyertai; f) Unsur syarat tambahan untuk dapat dituntut pidana; g) Unsur syarat tambahan untuk memperberat pidana; h) Unsur syarat tambahan untuk dapatnya dipidana. (Adami, 2000, 79)

Subjek tindak pidana adalah sesuatu yang oleh peraturan perundang-undangan dianggap dapat melakukan tindak pidana dan dapat dipertanggungjawabkan secara pidana atau dikenai sanksi pidana yang berdasarkan Undang-Undang dapat bertanggung jawab dan dikenai pidana. Subjek tindak pidana meliputi orang (manusia alamiah) dan korporasi (perserikatan) baik yang berstatus badan hukum maupun bukan badan hukum. .(Sudaryono dkk, 2005, hlm. 139)

Tindak pidana bidang kehutanan sendiri tidak diformulasikan dalam UU No. 41 Tahun 1999, tetapi berdasarkan Peraturan Menteri Kehutanan Nomor P.4. Menhut-II/ 2010 tentang Pengurusan Barang Bukti Tindak Pidana Kehutanan, yang dimaksud dengan tindak pidana kehutanan adalah perbuatan yang dilarang dan diancam pidana sebagai kejahatan atau pelanggaran sebagaimana diatur dalam Undang-Undang dibidang kehutanan dan konservasi kehutanan.

Subjek hukum dalam tindak pidana kehutanan adalah setiap orang, yaitu orang perseorangan dan/atau korporasi yang melakukan perbuatan perusakan hutan secara terorganisasi di wilayah hukuim Indonesia dan/atau berakibat hukm di wilayah hukum Indonesia.(Sudaryono dkk, 2005, hlm. 139). UUPPPK kemudian memberikan tafsir yang otentik terhadap kata-kata 'terorganisasi' yaitu sebagaimana disebutkan dalam Pasal 1 angka (6) yang bunyi lengkapnya sebagai berikut:

"Terorganisasi adalah kegiatan yang dilakukan oleh suatu kelompok yang terstruktur, yang terdiri dari 2 (dua) orang atau lebih, dan yang bertindak secara bersama-sama pada waktu tertentu dengan tujuan melakukan perusakan hutan, tidak termasuk kelompok masyarakat yang tinggal di dalam atau di sekitar kawasan hutan yang melakukan perladangan tradisional dan/atau melakukan penebangan kayu untuk keperluan sendiri dan tidak untuk tujuan komersial"

\section{Teori Kebijakan Hukum Pidana}

Istilah kebijakan dapat diambil dari istilah "policy" (Inggris) atau "politiek" (Belanda). Istilah kebijakan hukum pidana dapat pula disebut dengan istilah "politik 
hukum pidana", yang dalam kepustakaan asing istilah "politik hukum pidana" ini sering dikenal dengan berbagai istilah, antara lain "penal policy", "criminal law policy" atau "strafrechtspolitiek"( Barda, 2010, hlm. 26).

Pengertian kebijakan atau politik hukum pidana dapat dilihat dari politik hukum maupun dari politik kriminal. Menurut Sudarto politik hukum adalah usaha untuk mewujudkan peraturanperaturan yang baik sesuai dengan keadaan dan situasi pada suatu waktu. (Sudarto, 1981 hlm. 159). Selanjutnya, Sudarto menyatakan bahwa melaksanakan "politik hukum pidana" berarti mengadakan pemilihan untuk mencapai hasil Perundangundangan pidana yang paling baik dalam arti memenuhi syarat keadilan dan daya guna (Sudarto, $1981 \mathrm{hlm} .161$ ). , serta usaha mewujudkan peraturan perundang-undangan pidana yang sesuai dengan keadaan dan situasi pada suatu waktu dan untuk masamasa yang akan datang. (Sudarto, 28) Kebijakan kriminal (criminal policy) merupakan sebuah upaya rasional dari masyarakat dalam menanggulangi kejahatan.

\section{PEMBAHASAN}

\section{Implikasi Hukum Tindak Pidana Kehutanan Pasca Putusan MK No. 95/PUU-XII/2014}

Putusan Mahkamah Konstitusi Nomor 95/PUU-XII/2014 menambahkan bunyi ketentuan Pasal 50 ayat (3) huruf (e) dan (i) dengan prasa "kecuali masyarakat yang hidup secara turun temurun di dalam hutan dan tidak ditujukan untuk kepentingan komersial". Implikasi dari putusan ini adalah membuat setiap orang yang hidup di dalam hutan secara turun temurun tidak menjadi larangan lagi untuk menebang pohon, memungut hasil hutan atau memanen hasil hutan serta mengembalakan hewan ternak di dalam hutan walaupun tanpa izin dari pejabat yang berwenang.

Jika dicermati Pasal 50 merupakan ketentuan norma larangangan dalam UU Kehutanan dan ketentuan pidananya diatur pada Pasal 78. Artinya pengaturan norma larangan dan norma sanksinya diatur secara terpisah atau tidak dalam satu kesatuan rumusan pasal. Pengaturan norma larangan dengan norma sanksi yang terpisah tersebut, secara teoritis maupun empiris tidak menimbulkan permasalahan hukum, karena suatu perbuatan dapat dikatakan sebagai delik jika memenuhi unsur-unsur:

a. Suatu perbuatan manusia;

b. Perbuatan itu dilarang dan diancam dengan hukuman oleh Undang-Undang;

c. Perbuatan itu harus dilakukan oleh seseorang yang dapat dipertanggung jawabkan, artinya dipersalahkan karena telah melakukan perbuatan tersebut. (Satochid Kartanegara, 174)

Perbuatan yang dilarang dalam Pasal 50 ayat (3) huruf (e) dan (i) adalah "setiap orang dilarang: (e) menebang pohon atau memanen atau memungut hasil hutan di dalam hutan tanpa memiliki hak atau izin dari pejabat yang berwenang. (i) menggembalakan ternak di dalam kawasan hutan yang tidak ditunjuk secara khusus untuk maksud tersebut oleh pejabat yang berwenang". Terhadap perbuatan ini oleh Pasal 78 ayat (5) menyatakan bahwa "barang siapa dengan sengaja melanggar ketentuan sebagaimana dimaksud dalam Pasal 50 ayat (3) huruf e atau huruf f, diancam dengan pidana penjara paling lama 10 (sepuluh) tahun dan denda paling banyak Rp. 5.000.000.000,00 (lima miliar rupiah)". Dan ayat (8) berbunyi "barang siapa yang melanggar ketentuan sebagaimana dimaksud dalam Pasal 50 ayat (3) huruf i, diancam dengan pidana penjara paling lama 3 (tiga) bulan dan denda paling banyak Rp. 10.000.000.000,00 (sepuluh miliar rupiah)". 
Unsur "setiap orang" dalam Pasal 50 ayat (3) huruf (e) dan (i) adalah siapa saja baik orang (persoon) atau pribadi hukum (recht persoons) lainnya, yang melakukan tindakan secara terorganisasi menebang pohon atau memanen atau memungut hasil hutan di dalam hutan tanpa memiliki hak atau izin dari pejabat yang berwenang, dan/atau menggembalakan ternak di dalam kawasan hutan yang tidak ditunjuk secara khusus untuk maksud tersebut oleh pejabat yang berwenang.

Perubahan Pasal 50 ayat (3) huruf (e) dan huruf (i) setelah putusan MK menyebutkan ketentuan pidana kehutanan dikecualikan terhadap masyarakat yang secara turun temurun hidup di dalam hutan. Masyarakat yang turun temurun merupakan istilah umum yang dapat ditujukan kepada masyarakat adat maupun masyarakat lokal yang telah hidup di dalam kawasan hutan dari generasi ke generasi.

Subyek hukum tindak pidana kehutanan dalam hal ini dikecualikan bagi masyarakat yang hidup secara turun temurun di dalam hutan, sepanjang melakukan penebangan pohon, memanen, memungut hasil hutan dan beternak dalam kawasan hutan dilakukan bukan untuk kepentingan komersial. Istilah turun temurun bermakna beranak cucu untuk menunjukan bahwa masyarakat telah lebih dari dua generasi hidup di dalam hutan. Sehingga, untuk mengukur suatu masyarakat telah hidup secara turun temurun dibuktikan bahwa masyarakat telah hidup di dalam hutan lebih dari dua generasi.(Aminuddin

Menurut MK, tindak pidana dibidang kehutanan mempunyai karakter khusus dalam rangka memberikan perlindungan kepada masyarakat yang didukung perwujudannya melalui prinsip-prinsip, yaitu:

1) Prinsip Pencegahan Bahaya Lingkungan (Prevention of Harm) yang harus memenuhi adanya penyesuaian aturan nasional dengan aturan dan standar internasional untuk mencegah, mengurangi, dan mengontrol kerugian negara-negara lainnya akibat suatu kegiatan dalam skala nasional. Untuk melakukan itu setiap negara wajib mengatur setiap kegiatan masyarakatnya yang berpotensi merusak lingkungan, hutan dan sumber daya alam lainnya, karena masing-masing bagian ekosistem saling tergantung satu sama lain tanpa memandang batas-batas kewilayahan suatu negara.

2) Prinsip Kehati-hatian (Precautionary Principle), yaitu dapat diterapkan untuk menentukan kriteria seseorang yang bertanggungjawab dalam tindak pidana, meliputi kealpaan, yaitu orang yang menyebabkan kerusakan hutan harus bertanggungjawab apabila yang bersangkutan menerapkan kehati-hatian di bawah standar atau tidak menerapkan kehati-hatian sebagaimana mestinya.

3) Prinsip Pembangunan Berkelanjutan (Sustainable Development) yang menghendaki terjaminnya kualitas hidup yang layak dan baik bagi generasi sekarang dan yang akan datang melalui pelestarian daya dukung lingkungan, dengan maksud dalam proses pembangunan harus terdapat keseimbangan antara kepentingan ekonomi, sosial, serta pelestarian dan perlindungan lingkungan agar generasi yang akan datang memiliki kemampuan yang sama mendapatkan kualitas dari lingkungan hidup yang sehat dan baik.

Selain tiga prinsip di atas, menurut MK dalam menetapkan suatu tindakan sebagai tindak pidana dibidang kehutanan, Pemerintah dan DPR harus memperhatikan tujuan pembangunan nasional, yaitu mewujudkan masyarakat adil dan makmur, sehingga penanggulangan kejahatan 


\section{Terakreditasi Peringkat 5 (No. SK: 85/M/KPT/2020)}

kehutanan dilakukan demi kesejahteraan dan perlindungan masyarakat serta pengayoman masyarakat secara menyeluruh dan utuh, serta tidak menimbulkan kerugian material dan spiritual atas warga masyarakat.(Aminuddin

Salah satu elemen yang menjadi dasar MK untuk mengecualikan tindak pidana terhadap masyarakat yang turun temurun hidup di dalam hutan adalah kegiatan yang mereka lakukan tersebut ditujukan untuk memenuhi kebutuhan sandang, pangan dan papan sehari-hari, bukan untuk tujuan komersial. Secara implisit hal ini disampaikan oleh Mahkamah Konstitusi untuk menghindari praktik eksploitasi yang berlebihan yang dapat merusak kondisi hutan.(yance. Pengecualian tersebut hanya ditujukan kepada masyarakat yang hidup di dalam hutan, bukan untuk masyarakat yang berada di sekitar kawasan hutan. MK tidak menyebutkan secara jelas perbedaan antara masyarakat yang hidup di dalam hutan dengan masyarakat yang hidup atau berada di sekitar kawasan hutan. Namun untuk memberikan pemahaman yang jernih maka masyarakat yang hidup di dalam hutan harus dihubungkan dengan kebutuhannya yaitu:(aminuddin

1) Kebutuhan sandang (kebutuhan pakaian)

Kebutuhan sandang adalah kebutuhan akan pakaian yang kita kenakan setiap hari, mulai dari baju, celana, jaket, sepatu dan lain-lain. Setiap orang tidak bisa terlepas dari kebutuhan sandang karena kebutuhan sandang dikategorikan sebagai salah satu kebutuhan pokok.

2) Kebutuhan pangan (kebutuhan makanan)

Kebutuhan pangan adalah kebutuhan makanan setiap orang yang diperlukan untuk tubuh agar energinya tetap terjaga dan bisa beraktivitas dengan normal. Kebutuhan makanan dapat diperoleh secara langsung atau tidak langsung. Mendapatkan makanan secara tidak langsung bisa dengan cara mengkomersialkan sesuatu barang yang lain untuk mendapatkan makanan yang dibutukan.

3) Kebutuhan papan (kebutuhan perumahan) Kebutuhan papan adalah kebutuhan rumah sebagai tempat tinggal bagi setiap orang. Kebutuhan rumah yang layak tentu harus dengan menggunakan bahanbahan yang bisa bertahan lama.

Dengan demikian, yang dimaksud dengan masyarakat yang hidup di dalam hutan tidak harus masyarakat yang rumah tempat tinggalnya terdapat didalam hutan, melainkan masyarakat yang menggantungkan kebutuhan hidupnya untuk keperluan sandang, pangan dan papan dari hutan. Dengan kata lain hanya masyarakat yang memiliki relasi kehidupan yang kuat dengan hutan, melebihi relasi ekonomi, yang dikecualikan dari ketentuan tindak pidana dalam putusan MK.

Kegiatan masyarakat yang hidup dikawasan hutan tersebut tidak dapat dipidanakan kecuali dimaksudkan untuk kegiatan komersil. Namun dalam kenyataannya ada banyak pepohonan dan tumbuhan hutan lainnya yang ditanam sendiri oleh masyarakat, dipelihara dan dimanfaatkan hasilnya oleh masyarakat, terkadang untuk dijual atau dikomersialkan, di dalam kawasan hutan mereka yang ditunjuk oleh Pemerintah untuk dijadikan sebagai kawasan hutan dan diperlakukan oleh pemerintah sebagai hutan negara. Hal lain misalkan ketentuan Pasal 50 ayat (3) huruf (i) UU Kehutanan mengenai beternak dalam kawasan hutan. Masyarakat seringkali beternak hewan seperti ayam, kambing, dan sapi di dalam hutan yang ditujukan untuk dijual atau dikomersialkan guna memenuhi kebutuhannya. Oleh karena itu, pembatasan MK mengenai bukan untuk tujuan komersial harus dipandang sebagai upaya untuk 
melindungi hutan dari kerusakan yang tidak dikehendaki.(Yance dkk,)

Pengecualian tindak pidana dalam Pasal 50 ayat (3) huruf (e) dan huruf (i) UU Kehutanan berlaku terhadap tindak pidana yang terjadi di atas kawasan yang diperlakukan oleh pemerintah sebagai hutan negara. Jadi ketentuan pidana, termasuk pengecualian pidana, tidak berlaku pada hutan adat sebab di atas hutan adat berlaku hukum adat.

2. Kebijakan Hukum Pidana Dalam Tindak Pidana Kehutanan Pasca Putusan MK No. 95/PUU-XII/2014

UUPPPK dan UU Kehutanan merupakan instrumen kebijakan hukum pidana yang ditujukan untuk mendukung upaya pemanfaatan dan pengelolaan kawasan hutan agar tercapai kesejahteraan sosial bagi masyarakat. Kebijakan hukum pidana ini sesungguhnya hadir sebagai sebuah upaya rasional untuk menanggulangi kejahatan perusakan hutan yang terorganisasi seperti pembalakan liar, penambangan tanpa izin, dan perkebunan tanpa izin yang dilakukan secara rapi dan terorganisasi serta melibatkan banyak aktor baik nasional maupun internasional. Para aktor tersebut mempunyai kekuatan modal dan kekuatan politik yang sangat besar sehingga dalam menjalankan kejahatan sangat susah untuk terjerat proses hukum.

Kebijakan hukum pidana (penal policy) yang ada dalam UUPPPK dan UU Kehutanan disatu sisi memang ditujukan untuk menanggulangi kejahatan perusakan hutan, namun disisi lain dapat menimbulkan ketidakadilan berkaitan dengan eksesnya bagi masyarakat yang hidup di dalam dan sekitar kawasan hutan termasuk bagi masyarakat hukum adat. Hal ini bisa dilihat dari kebijakan kriminalisasi dalam skema kebijakan hukum pidana tersebut dimana beberapa diantaranya sangat berpotensi digunakan untuk melakukan tindakan kriminalisasi terhadap anggota masyarakat hukum adat khususnya yang berkaitan dengan kegiatan tanpa izin.

Izin kemudian menjadi sebuah instrumen yang sangat penting dan dijadikan sebagai sebuah dasar dalam merumuskan kebijakan formulasi hukum pidana kehutanan. Setiap tindakan yang dilakukan di kawasan hutan dimana tindakan tersebut tanpa disertai dengan izin, maka tindakan tersebut merupakan sebuah tindak pidana. Secara singkat, tolak ukur kejahatan yang dilakukan oleh seseorang maupun badan hukum di dalam kawasan hutan hanya dengan melihat ada atau tidaknya izin. Paradigma semacam ini kemudian mengkonstruksikan bahwa seseorang atau badan hukum yang telah memiliki izin maka tidak melakukan perusakan hutan. Jika konstruksi delik formil semacam ini dikedepankan, maka masyarakat hukum adat yang hampir bisa dipastikan tidak memiliki izin akan banyak terkena dampak dari adanya kebijakan formulasi (kriminalisasi) tersebut. Padahal jika hendak konsisten dengan tujuan dari kebijakan hukum pidana (penal policy) yang ditujukan untuk menanggulangi kejahatan di bidang perusakan hutan yang teroganisasi, maka tolak ukur yang dipakai seharusnya adalah ada atau tidaknya kerusakan hutan yang ditimbulkan bukan pada ada atau tidaknya izin. Jika paradigma seperti ini yang dipakai, maka seseorang atau badan hukum yang sudah memiliki izin pun dapat dipidanakan selama yang bersangkutan melakukan perusakan hutan.( Rizka Fakhry Alfiananda, 2018 hlm, 10)

Kehadiran putusan MK No. 95/PUUXII/2014 telah menafsirkan bagaimana ketentuan tindak pidana kehutanan harus diterapkan, khususnya terkait Pasal 50 ayat (3) huruf (e) dan (i), dimana ketentuan pidana kehutanan semestinya ditujukan kepada kejahatan yang teorganisasi yang 
telah menimbulkan kerusakan, baik dari aspek ekonomi, aspek lingkungan, maupun aspek sosial. Agus Setyarso dalam keterangannya sebagai ahli dalam putusan ini menyampaikan bahwa penebangan yang dilakukan oleh individu masyarakat di dalam dan di sekitar kawasan hutan seharusnya menimbulkan kewajiban pemerintah untuk memberikan pelayanan, sehingga mereka mampu meningkatkan kehidupannya bersandingan dengan keberlanjutan sumber daya hutan di sekelilingnya. Prof. Achmad Sodiki, ahli yang juga dihadirkan pemohon menyatakan bahwa pasal-pasal kriminalisasi dalam UUPPPH dan UU Kehutanan seharusya dianggap sebagai konstitusional bersyarat sepanjang tidak memasukkan perbuatan yang dilakukan oleh masyarakat hukum adat sesuai dengan ketentuan hukum adat.

Putusan MK No. 95/PUU-XII/2014 ini memberikan pengaruh penting dalam tindak pidana kehutanan. Putusan ini melahirkan 2 (dua) prinsip penting dalam pengaturan dan pelaksanaan tindak pidana kehutanan, yaitu:

1. Prinsip pengecualian tindak pidana kepada "masyarakat yang secara turun temurun hidup di dalam hutan karena memanfaatkan sumber daya hutan untuk kepentingannya sendiri, bukan untuk tujuan komersial".

Prinsip ini menjadi panduan bagi pembentuk dan pelaksana peraturan perundang-undangan di bidang kehutanan. Dalam penerapan ketentuan pidana kehutanan, maka aparatur hukum harus pertama-tama memeriksa apakah masyarakat yang diperiksa memenuhi prinsip tersebut. Menjadi kekeliruan dalam penerapan ketentuan pidana kepada masyarakat dimana wilayah kehidupannya telah ditetapkan secara sepihak oleh pemerintah sebagai kawasan hutan, kemudian mengkriminalisasi masyarakat di dalam hutan.
Secara definitif kawasan hutan merupakan tanah yang telah ditetapkan oleh Pemerintah sebagai kawasan hutan. Dari situ baru ditentukan keberadaan hutan negara. Namun dalam praktiknya, kawasan yang baru ditunjuk untuk dijadikan sebagai kawasan hutan telah diperlakukan secara definitif oleh pemerintah sebagai hutan negara. Selama ini Pengadilan mengabaikan permasalahan ketidakabsahan kawasan hutan dan menyatakan bahwa ketentuan pidana dapat diperlakukan di atas kawasan yang belum definitif sebagai kawasan hutan. Pengecualian yang diputusankan oleh MK dalam putusan ini bukan saja menghindari masyarakat dari kriminalisasi di atas kawasan hutan yang belum definitif, tetapi juga membuka peluang untuk menyelesaikan konflik tenurial dan menghindari kriminalisasi.

Sehingga pengecualian tindak pidana dalam putusan MK ini berlaku terhadap tindak pidana yang terjadi di atas kawasan yang diperlakukan oleh pemerintah sebagai hutan negara. Jadi ketentuan pidana, termasuk pengecualian pidana, tidak berlaku pada hutan adat sebab di atas hutan adat berlaku hukum adat.

Kemudian prinsip pengecualian tindak pidana ini sebenarnya sudah sejalan dengan ketentuan dalam UUPPPH, misalkan Pasal 1 angka (6), dan Pasal 11 UUPPPH. Namun terdapat beberapa inkonsistensi dalam UUPPPH, misalnya kepada masyarakat yang secara turun temurun hidup di dalam hutan masih harus memerlukan izin untuk memanfaatkan hutan dari pemerintah. Inkonsistensi lain terjadi karena banyak ketentuan dalam UUPPPH tidak mengatur pengecualian terhadap masyarakat yang hidup secara turun temurun di dalam hutan sehingga banyak menjerat masyarakat adat. 
2. Prinsip penerapan hukum pidana kehutanan haruslah dipandang sebagai upaya terakhir (ultimum remedium).

Prinsip dengan pendekatan pidana ini merupakan upaya terakhir yang harus dilakukan dalam menyelesaikan konflik tenurial kehutanan. Sehingga dalam menghadapi konflik tenurial kehutanan, pemerintah harus melakukan pendekatan sosial persuasif untuk memperoleh solusi secara damai. Hal ini sejalan dengan Putusan MK No. 55/ PUU-VII/2010 mengenai pengujian ketentuan pidana dalam UU Perkebunan. Dalam putusan tersebut MK menyatakan bahwa dalam menghadapi konfik tenurial harus terlebih dahulu diselesaikan secara perdata dari pada melakukan pendekatan represif melalui ketentuan pidana.

Prinsip ini juga haruslah diikuti dengan cara atau mekanisme lain dalam penyelesaian konflik kehutanan. Beberapa mekanisme lain yang dapat ditempuh antara lain adalah musyawarah atau kerjasama di dalam perencanaan dan pengelolaan hutan. Dalam konteks Indonesia, mekanisme ini tentunya terasa sangat penting untuk dipakai oleh aparatur negara terutama dengan mengingat bahwa ketentuan kriminalisasi yang diatur setidaknya di dalam UUPPPH dan UU Kehutanan dibangun di atas suatu fakta bahwa objek pengaturannya belumlah jelas, apakah hutan negara ataukah hutan hak, yang termasuk di dalamnya adalah hutan adat.

Penyelesaian konflik dengan mekanisme tersebut tidak hanya penting dan perlu tetapi juga sangat mendesak karena menyangkut keselamatan warga negara. Oleh karena itu, pemerintah harus membangun insitusi yang efektif untuk menyelesaikan konflik tenurial kehutanan. Penyelesaian konflik tenurial kehutanan haruslah diselenggarakan dengan cara bermartabat tanpa kekerasan, Negara harus Hadir guna melindungi segenap bangsa dan memberikan rasa aman kepada seluruh warga negara.(Aminuddin

Sebagai upaya penyelesaian konflik kehutanan, Negara (Pemerintah) seharusnya dapat membangun kerjasama dengan masyarakat hukum adat. Menurut Ahmad Sodiki dalam keahliannya menyatakan bahwa masyarakat hukum adat tersebut akan mencermati apakah pembalakan liar dilakukan oleh anggota masyarakat hukum adat sendiri atau bukan, sehingga upaya untuk mencegah pembalakan liar akan efektif apabila terbangun kerjasama antara pemerintah dengan masyarakat adat.

Kebijakan hukum pidana pasca putusan MK No. 95/PUU-XII/2014 dalam mencegah dan pemberantasan kerusakan hutan harus dilihat secara holistik. Pemahaman secara holistik akan mendobrak paradigma positivistik yang selama ini menghinggapi kebijakan hukum pidana (penal policy) dengan asas legalitasnya. Paradigma positivistik yang digunakan oleh kebijakan hukum pidana dalam implementasinya membalik kredo, hukum adalah untuk manusia, menjadi manusia untuk hukum. Hal ini terlihat jelas pada pemaksaan ketertundukan manusia terhadap rumusan tindak pidana yang ada. Atas adanya realitas sosial seperti ini maka bisa dikatakan bahwa kebijakan hukum pidana (penal policy) memposisikan manusia lebih rendah daripada hukum. Pemahaman yang demikian sangat relevan digunakan dalam skema kebijakan hukum pidana terkait tindak pidana kehutanan dalam melihat keberadaan masyarakat hukum adat atau masyarakat yang secara turun temurun hidup di dalam hutan. Oleh karena itu aparat penegak hukum tidak 
boleh berparadigma positivistik an sich. Jangan hanya karena masyarakat hukum adat memenuhi perbuatan yang sesuai dengan rumusan tindak pidana kemudian mereka dipidanakan. Aparat penegak hukum harus melihat latar belakang sosio-kultural mereka sebagai bagian dari usaha menegakkan hukum secara holistik.

Putusan MK tersebut telah menegaskan bahwa tidak dapat dipidana masyarakat adat hanya karena melakukan perbuatan-perbuatan untuk memenuhi kebutuhan hidup mereka, seperti mengambil kayu, berkebun, berternak dan lain-lain. Apalagi perbuatan mereka tidak salah menurut hukum adat mereka serta hukum adat mereka mengatakan bahwa hutan tersebut merupakan hutan adat.

MK melalui putusannya tersebut juga telah melakukan sebuah upaya afirmasi atas keberadaan masyarakat hukum adat yang berada di sekitar kawasan hutan, dengan melihat bahwa masyarakat yang mempunyai relasi kehidupan yang sangat kuat dengan hutan harus dikecualikan dari ketentuan pidana. Atas ketentuan tersebut, baik pembentuk maupun pelaksana kebijakan hukum pidana (penal policy) harus menjadikannya sebagai panduan.

Meskipun pengecualian itu hanya terhadap ketentuan Pasal 50 ayat (3) huruf (e) dan (I) UU Kehutanan, namun pembentuk dan terutama pelaksana kebijakan hukum pidana (penal policy) harus mempertimbangkan pelaksanaannya di dalam ketentuan lain yang bersinggungan langsung dengan masyarakat hukum adat utamanya pasalpasal pidana di dalam UUPPPH. Jika ini dapat dilakukan dengan baik, maka rezim kriminalisasi terhadap masyarakat hukum adat yang terjadi secara turun temurun akan berakhir.

Kemudian dalam skema kebijakan di luar hukum pidana (non penal policy) yang diarahkan untuk melakukan pencegahan terhadap perusakan hutan juga harus didasarkan pada pemahaman secara holistik. Pemahaman yang holistik ini akan mendorong keterlibatan masyarakat hukum adat di dalam skema pencegahan perusakan hutan. Jangan hanya karena masyarakat hukum adat tidak memiliki izin di dalam pengelolaan dan pemanfaatan kawasan hutan kemudian tidak dilibatkan dalam skema tersebut.

Dengan demikian, para perumus kebijakan harus memahami adanya keterikatan yang luar biasa antara masyarakat hukum adat dengan kawasan hutan. Mereka akan mempunyai tatanan sosial sendiri di dalam perlindungan kawasan hutan. Mereka mempunyai sistem sanksi tersendiri sebagai wujud kontrol terhadap kawasan hutan dan hal itu dipatuhi oleh seluruh anggota dari masyarakat hukum adat tersebut. Semua stakeholder yang terlibat di dalam sebuah skema kebijakan hukum pidana kehutanan baik itu Dewan Perwakilan Rakyat sebagai pembentuk Undang-Undang maupun aparat penegak hukum yang meliputi Polisi, Jaksa, Advokat, dan Hakim harus menyamakan persepsi terkait keberadaan masyarakat hukum adat. Penyamaan persepsi ini terkait keberadaan masyarakat hukum adat yang merupakan sebuah entitas khusus di dalam kerangka Negara Kesatuan Republik Indonesia yang mempunyai kekhususan dalam tatanan sosialnya khususnya yang berkaitan dengan pengelolaan dan pemanfaatan kawasan hutan. Pemahaman secara holistik harus dikedepankan guna melihat realitas tersebut.

\section{KESIMPULAN}


Berdasarkan pembahasan penelitian tindak pidana kehutanan pasca putusan MK No. 95/PUU-XII/2014 maka dapat ditarik kesimpulan bahwa:

1. Implikasi hukum tindak pidana kehutanan pasca putusan MK No. 95/PUU-XII/2014 melahirkan pengecualian terhadap subjek hukum tindak pidana kehutanan. Prasa "setiap orang" dalam Pasal 50 ayat (3) huruf (e) dan (I) UU Kehutanan, dikecualikan terhadap masyarakat yang secara turun temurun hidup di dalam hutan. Masyarakat yang turun temurun merupakan istilah umum yang dapat ditujukan kepada masyarakat adat maupun masyarakat lokal yang telah hidup di dalam hutan dari generasi ke generasi. Masyarakat yang hidup secara turun temurun dapat dilihat dari ciri telah hidup minimal dua generasi sebelumnya.Hidup di dalam hutan dapat disandingkan atau dikaitkan dengan kebutuhan sandang, kebutuhan papan, kebutuhan pangan dan kebutuhan sosial budaya atau spiritual yang telah turun temurun bergantung dengan hutan yang tidak ditujukan untuk kepentingan komersial. Bukan untuk tujuan komersial dalam hal ini dipandang sebagai upaya untuk melindungi hutan dari kerusakan yang tidak dikehendaki.

2. Kebijakan hukum pidana dalam tindak pidana kehutanan pasca putusan MK No. 95/PUU-XII/2014 menciptakan kebijakan afirmasi bagi masyarakat adat atau Aminuddin, Lalu Parman, Lalu Sabardi, Subjek Hukum Dalam Tindak Pidana Kehutanan Pasca Putusan Mahkamah Konstitusi Nomor 95/PUU-XII/2014, Jurnal Education and Development, Institut Pendidikan Tapanuli Selatan, Vol. 7 No. 3 Edisi Agustus 2019. masyarakat yang hidup secara turun temurun di dalam hutan. Kebijakan hukum pidana harus dilihat sebagai upaya memahami pencegahan dan pemberantasan kerusakan hutan yang harus dilihat secara holistik, yaitu melalui skema kebijakan di dalam hukum pidana dan diluar hukum pidana, bukan sebagai upaya mengkriminalisasi masyarakat adat atau masyarakat yang hidup secara turun temurun di dalam hutan. Dalam skema kebijakan di dalam hukum pidana, aparat penegak hukum tidak boleh melihat formulasi kebijakan hukum pidana secara positivistik an sich, namun harus mempertimbangkan bagaimana melihat latar belakang sosio-kultural masyarakat adat atau masyarakat yang hidup secara turun temurun di dalam hutan sebagai bagian dari usaha menegakkan hukum pencegahan dan pemberantasan kerusakan hutan. Putusan MK No. 95/PUU-XII/2014 muncul sebagai upaya mendobrak paradigma kebijakan hukum pidana yang positivistik dengan asas legalitasnya. Kemudian skema kebijakan diluar hukum pidana harus dilakukan dengann mendorong keterlibatan masyarakat hukum adat di dalam skema pencegahan perusakan hutan, karena mereka mempunyai tatanan sosial dan mempunyai sistem sanksi tersendiri sebagai wujud kontrol di dalam perlindungan kawasan hutan.

\section{DAFTAR PUSTAKA}

Komnas HAM, Inquiri Nasional, Ringkasan Temuan 2016.

Yance Arizona, Erasmus Cahyadi, dan Malik, anotasi putusan mahkamah konstitusi nomor 95/puu-xii/2014 mengenai pengujian undangundang no. 18 tahun 2013 tentang pencegahan dan pemberantasan perusakan hutan, dan undang- 
undang no. 41 tahun 1999 tentang kehutanan, epistema institute dan Aliansi Masyarakat Adat Nusantara (AMAN), 2015.

Wirjono Projodikoro, Asas-Asas Hukum Pidana di Indonesia, Refika Aditama, Bandung, 2003.

Andi Hamzah, 2001, Asas-Asas Hukum Pidana, Jakarta: Rineka Cipta.

Barda Nawawi Arief , 2002, Kebijakan Hukum Pidana, Bandung: PT. Citra Aditya Bakti.

Adami Chazawi, 2000, Pelajaran Hukum Pidana Bag I, Jakarta: Raja Grafindo.

Sudaryono \& Natangsa Surbakti, 2005, Buku Pegangan Kuliah Hukum Pidana, Surakarta: Fakultas Hukum UMS.

Undang-Undang Nomor 18 Tahun 2013 tentang Pencegahan dan Pemberantasan Perusakan Hutan.

Barda Nawawi Arief, Bunga Rampai Kebijakan Hukum Pidana: (Perkembangan Penyusunan Konsep KUHP Baru), Edisi Pertama, Cetakan ke-2, Kencana Prenada Media Group, Jakarta, 2010.

Sudarto, Hukum dan Hukum Pidana, Alumni, Bandung, 1981.

Sudarto, Hukum Pidana dan Perkembangan Masyarakat, Sinar Baru, Bandung, 1983.

Satochid Kartanegara, Hukum Pidana, Bagian I, (Balai Lektur Mahasiswa, Tanpa tahun).

Mahkamah Konstitusi, Putusan MK Nomor 95/PUU-XII/2014

Koalisi Masyarakat Sipil Untuk Kelesatrian Hutan, 2013, Public Review Terhadap Rancangan UndangUndang tentang Pemberantasan Perusakan Hutan, Indonesia
Corruption Watch dan Perkumpulan HuMa, Jakarta.

Rizka Fakhry Alfiananda, Masyarakat Hukum Adat Dalam Skema Kebijakan Kriminal (Criminal Policy) Di Bidang Perusakan Hutan, Jurnal, Wacana Hukum, Vol.XXIV, No.2, Desember 2018. 